\title{
Sequencial passages of the multiple nucleopolyhedrovirus of Anagrapha falcifera (Kirby) (Lepidoptera: Noctuidae) (AfMNPV) in Spodoptera cosmioides (Walker) (Lepidoptera, Noctuidae)
}

\section{Passagens sequenciais do múltiplo nucleopoliedrovírus de Anagrapha falcifera (Kirby) (Lepidoptera: Noctuidae) (AfMNPV) em Spodoptera cosmioides (Walker) (Lepidoptera, Noctuidae)}

\author{
Maurício Lara Moscardi ${ }^{1}$, Viviane Dutra ${ }^{2}$, Pablo Kruger \\ Fernandes $^{3}$, Samuel Roggia ${ }^{4}$, Sheila Michele Levy ${ }^{5}$, \\ Angela Maria Ferreira Falleiros ${ }^{6}$
}

\begin{abstract}
The aim of this work was to evaluate the effects of Anagrapha falcifera multiple nucleopolyhedrovirus (AfMNPV) passages in the Spodoptera cosmioides caterpillar's biology at different times of infection and histological changes that the virus could cause in the caterpillar midgut, seeking correlate histopathologic effects to the effectiveness of this virus as a potential biological control of this pest. Larvae were infected with seven days of development, by using three different passages of AfMNPV on S. cosmioides (F1, F4 and F7, which is the first, fourth and seventh passages, respectively) and the control treatment. Compared biology assays with the same treatments for analyzing behavior and mortality of caterpillars were performed concomitantly. The midgut morphology was compared between infected and uninfected larvae. The digestive tubes were collected at 24, 72 and 144 hours of infection (20 tubes/treatment/time of infection). After collection, the digestive tubes were fixed in Karnovsky, processed, stained with Hematoxylin-Eosin, and examined under a light microscope. The biology results of F4 and F7treatments, showed a drastic reduction in locomotion and feeding from the fourth day after infection and higher cumulative mortality rate compared to the control and F1. All treatments caused morphological changes in the midgut of $S$. cosmioides, in the three times of
\end{abstract}

${ }^{1}$ Doutorado em Agronomia (Fitossanidade/Entomologia) pelo Programa de Pós-graduação da Universidade Estadual de Londrina (UEL), Londrina, Paraná, Brasil. Coordenador de Pesquisa e Registro na Andermatt do Brasil Soluções Biológicas, Curitiba, Paraná, Brasil.E-mail: mauriciomoscardi@hotmail.com

${ }^{2}$ Doutorado em Agronomia (Fitossanidade/Entomologia) pelo Programa de Pós-graduação da Universidade Estadual de Londrina, Londrina, Paraná, Brasil. Gerente Técnica na Andermatt do Brasil Soluções Biológicas, Curitiba, Paraná, Brasil.

${ }^{3}$ Graduação em Ciências Biológicas pela Universidade Estadual de Londrina, Londrina, Paraná, Brasil.

${ }^{4}$ Doutorado em Entomologia pela Escola Superior de Agricultura "Luiz de Queiroz" da Universidade de São Paulo (Esalq-USP), Piracicaba, São Paulo, Brasil. Pesquisador na Embrapa Soja, Setor de Entomologia, Londrina, Paraná, Brasil.

${ }^{5}$ Doutorado em Ciências Biológicas (Zoologia) pela Universidade Estadual Paulista "Júlio de Mesquita Filho" (Unesp), Botucatu, São Paulo, Brasil. Professora Associada do Departamento de Histologia do Centro de Ciências Biológicas da Universidade Estadual de Londrina, Londrina, Paraná, Brasil.

${ }^{6}$ Doutorado em Ciências Biológicas (Anatomia Humana) pela Universidade Estadual Paulista "Júlio de Mesquita Filho", Botucatu, São Paulo, Brasil. Professora Associada do Departamento de Histologia do Centro de Ciências Biológicas da Universidade Estadual de Londrina, Londrina, Paraná, Brasil. 
infection, with the greatest changes occurring at the epithelium. The AfMNPV, in the three passages tested in $S$. cosmioides, caused behavioral and morphological changes in the midgut, indicating that it can be a promising agent for biological control of this pest.

Keywords: Morphology; Histopathology; Biological control; Insect viruses.

\section{Resumo}

O objetivo deste trabalho foi avaliar os efeitos de passagens do múltiplo nucleopoliedrovírus de Anagrapha falcifera (AfMNPV) na biologia de lagartas de Spodoptera cosmioides, em diferentes momentos de infecção, e as alterações histológicas que o vírus poderia causar no intestino médio da lagarta, buscando correlacionar os efeitos histopatológicos e a eficácia deste vírus, como um potencial controle biológico desta praga. As lagartas foram infectadas com sete dias de desenvolvimento, utilizando três passagens diferentes do AfMNPV em S. cosmioides (F1, F4 e F7, sendo a primeira, quarta e sétima passagens, respectivamente) e o tratamento controle. Foram realizados, concomitantemente, ensaios de biologia, comparados com os mesmos tratamentos, para analisar o comportamento e mortalidade das lagartas. A morfologia do intestino médio foi comparada entre as lagartas infectadas e as não infectadas. Os tubos digestivos foram coletados com 24, 72 e 144 horas de infecção (20 tubos/tratamento/ tempo de infecção). Após a coleta, os tubos foram fixados em Karnovsky, processados, corados com Hematoxilina-Eosina e analisados ao microscópio de luz. Os resultados da biologia dos tratamentos F4 e F7 mostraram uma redução drástica na locomoção e alimentação das lagartas, a partir do quarto dia pós-infecção e maior taxa de mortalidade cumulativa, em relação ao controle e F1. Morfologicamente, todos os tratamentos causaram alterações no intestino médio das lagartas de $S$. cosmioides, nos três tempos de infecção, sendo que as maiores alterações ocorreram no epitélio. O AfMNPV, nas três passagens testadas em $S$. cosmioides, provocou alterações comportamentais e morfológicas no intestino médio, indicando que pode ser um promissor agente de controle biológico desta praga.

Palavras-chave: Morfologia; Histopatologia; Controle biológico; Vírus de insetos.

\section{Introduction}

Spodoptera cosmioides is a polyphagous species, once considered a minor pest, it has been showing significant increases in attacks on crops. In Brazil, $S$. cosmioides is the second most frequent species of the genus collected in agricultural landscapes, second only to $S$. frugiperda, the main pest species of the genus. Nevetheless, S. cosmioides encompass only about $10 \%$ of the catches. There is evidence that $S$. cosmioides is not affected by harsh dry or wet seasons and is not greatly affected by the El Niño. The intensification of the effects of these phenomena due to the climate change may contribute to turn $S$. cosmioides to an important pest species in the future. ${ }^{(1)}$ Some outbreaks of this species are reported in the literature associated with frequent applications of broad-spectrum insecticides, which destroy the fauna of natural enemies related to this specie. (2) Thus, alternative control methods now have greater importance for the containment of this pest. From the implementation of the Integrated Pest Management (IPM) program in soybeans crops, the maintenance of the natural enemies' complex in agroecosystems, and the development of alternatives to chemical control of insects have been the subject of several studies. The control of this pest from the use of entomopathogenic agents has been studied, and the Anagrapha falcifera multiple nucleopolyhedrovirus (AfMNPV) is a promising alternative.

A study conducted by Hostetter and Puttler, ${ }^{(3)}$ showed that more than 31 species of Lepidoptera from ten different families are likely to AfMNPV, and no other baculovirus, natural or genetically modified, known currently infects many economically important and cosmopolitan species of insects, causing high mortality even at low dosages. Among the entomopathogenic viruses as biopesticides, the Baculoviridae family, which belongs the 
AfMNPV, is the most studied because of its large specific virus/insect and its potential as a biological control agent, and it can be used as biological alternatives to chemical pesticides. ${ }^{(4-6)}$ The baculovirus associated with Lepidoptera have a mode of action that is initiated by the ingestion of nucleopolyhedrovirus (NPV) by the host insect. After ingestion, the occlusion bodies dissolve in the midgut lumen, releasing the virions constituting infection. The infected larvae lose a motor and power capacity in about four days after feeding and die six to ten days after infection. ${ }^{(7)}$

In insects, the midgut is the primary site of digestion and absorption of food, and the main access to chemical and biological insecticides. The midgut is formed by epithelial layer mainly composed of columnar, goblet, regenerative and endocrine cells, coated internally by peritrophic membrane and supported externally in the muscular layer. ${ }^{(8-9)}$ These cells are responsible for the functions of synthesis and secretion of digestive enzymes, absorption of water and nutrients, ion exchange, replacement of epithelial cells in disposal, providing maintenance of epithelial integrity, the synthesis of polypeptide hormones that act on differentiation of the cells and regenerative control of digestive enzyme secretion after meals. ${ }^{(8-9)}$ Changes in midgut can affect the growth and development of insects, as well as all physiological events. ${ }^{(10-11)}$

Thus, the objectives of this study were to evaluate the effects of Anagrapha falcifera multiple nucleopolyhedrovirus (AfMNPV) passages in the $S$. cosmioides caterpillar's biology at different times of infection and histological changes that the virus could cause in the caterpillar midgut, seeking correlate histopathologic effects to the effectiveness of this virus as a potential biological control of this pest.

\section{Material and Methods}

\section{Insects}

The eggs of Spodoptera cosmioides were obtained from the insect rearing facility at the Centro
Nacional de Pesquisa de Soja (Embrapa Soja), Londrina, Paraná State, Brazil. The moths were maintained in the laboratory on an artificial diet under controlled temperature $\left(25^{\circ} \mathrm{C}-27^{\circ} \mathrm{C}\right)$, photoperiod $(14 \mathrm{~L} / 10 \mathrm{D})$ and $80 \%$ relative humidity, inside plastic cages for mating and oviposition.

The $S$. cosmioides moths put the eggs on a white paper that covered the inside walls of the cage; this paper was removed, the eggs were washed and transferred to the cardboard paper, that was placed on cardboard cups (ice cream type). The newly hatched caterpillars started to feed on the diet, remaining in this cup until the pre-pupal stage. Then, the insects were transferred to plastic boxes (gerbox type) until the pupae stage, which were separated by sex and placed in the cages for mating and oviposition, in the ratio of a male to a female. After the eggs hatched, the larvae were maintained in the same diet and monitored until the 7th day after hatching, as we proceeded with the virus infection.

\section{Obtaining sequential passages of Anagrapha falcifera (AfMNPV) baculovirus}

Sequential passages of the AfMNPV virus were performed in $S$. cosmioides, to study the effectiveness of control in this species. Passages collection occurred from the caterpillar's infection with AfMNPV pure viral suspension. For infection, diet cubes were dipped for five seconds in viral suspension and provided to the caterpillars for 48 hours. After this period, the diet used was virusfree. Caterpillars were monitored daily and when they experienced symptoms of infection or death, they were collected and stored at $-20{ }^{\circ} \mathrm{C}$ for subsequent extraction of the virus.

For extraction, caterpillars were macerated in crucible. Such mash was transferred to a funnel covered with cotton and gauze, in which was added distilled water for filtering. After extraction, the material was centrifuged in ultracentrifuge at $10,000 \mathrm{rpm}$ to remove impurities such as grease, membrane debris and filtering water, having the purified virus. This virus, after purification, was 
considered a passage ( $1^{\text {st }}$ pass $)$, i.e., underwent a process infection within the target organisms and was isolated, allowing a new process infection in young individuals, giving rise to a new passage. Eight virus passages were performed and, for biology and midgut morphology studies presented here, we used the first (F1), fourth (F4) and seventh passages (F7), which in previous experimental protocols were shown to be more consistent with the focus of this work.

\section{Biological characteristics of AfMNPV-infected S. cosmioides}

Three treatments, F1, F4, F7, and a concentration of $6.5 \times 10^{5}, 8.28 \times 10^{7}$ and $5.575 \times 10^{8} \mathrm{OB}$. $\mathrm{mL}^{-1}$ respectively were used. The control was composed only of distilled water. Infection occurred as described previously and for the control treatment, the diet cubes were dipped in distilled water. We used 60 caterpillars/treatment, which were individually placed in plastic containers with diet. Biological parameters (change of instar by observing the expulsion of the head capsule, deformation after molting and/or adult emergence and mortality of individuals) were assessed daily until adult emergence. There was variance analysis by the Kruskal-Wallis test and comparison of means by Student-Newman-Keuls tests, $\mathrm{p}<0.05$.

It was also carried out the counting of the viral polyhedron at five and ten days after infection. For viral counts we used 10 caterpillars/treatment/ infection days, in which caterpillars were subjected to virus extraction process described above. For filtration it was used $50 \mathrm{~mL}$ of distilled water and the obtained samples were not passed through the purification process. The polyhedrons counting in OB.mL ${ }^{-1}$ was held in Neubauer Chamber.

\section{Midgut morphology of AfMNPV-infected S. cosmioides}

The same three biology experiment treatments were used, and the procedure was performed at the Laboratório de Insetos (LI), Departamento de Histologia, Universidade Estadual de Londrina (UEL), Londrina, Paraná, Brazil. The midguts (20 tubes/treatment/infection period) were collected at 24 hours, 72 hours and 144 hours, following infection and used in the study. For collection, S. cosmioides larvae were anaesthetized by cooling at $4{ }^{\circ} \mathrm{C}$ and dissected under a stereoscope microscope with saline solution for dissecting insects $(1.80 \mathrm{~g}$ $\mathrm{NaCl}, 1.88 \mathrm{~g} \mathrm{KCl}, 0.16 \mathrm{CaCl} ; 0.004$ g NaHCO 3 and $100 \mathrm{~mL}$ distilled water). The digestive tubes were fixed in Karnovsky's fixative solution $(2.5 \%$ glutaraldehyde $+4.0 \%$ paraformaldehyde in $0.1 \mathrm{M}$ phosphate buffer and $\mathrm{pH}$ 7.2) for six hours. After fixing, the material was included in Historesin ${ }^{\circledR}$ Leica, following the manufacturer's recommendations. The material was cut in a rotary microtome (Leica RM 2145) into $5 \mu \mathrm{m}$ and placed on glass slides previously cleaned with ethyl ether and absolute alcohol. The sections were stained with Harris Hematoxylin and Eosin (H-E), according to the protocol of the LI and mounted in Canada balsam. After drying, they were analyzed in under a light microscope (Axiophot, Zeiss).

\section{Results}

\section{Mortality and development time of AfMNPV-infected S. cosmioides}

Mortality results are shown in Table 1 . The caterpillars began to die from the eighth day after infection (DAI), but from the fourth DAI on, the caterpillars of the F4 and F7 treatments decreased their feeding. From the seventh DAI on, these caterpillars stopped feeding and showed drastic reduction in dietary consumption. Along with the feeding reduction, the development of these caterpillars was greatly affected, as shown in Figure 1. F1 treatment caterpillars, although they have not shown statistical difference in mortality compared with the control, showed adult deformation rate of $30 \%$, compared with none in the control. The results of virus counting are shown in Table 2. 
Table 1 - Cumulative mortality ( $\% \pm$ standard error) of $S$. cosmioides caterpillars infected with different passages of AfMNPV.

\begin{tabular}{|c|c|c|c|c|c|c|}
\hline \multirow{3}{*}{$\begin{array}{c}\text { Treatments } \\
\text { Control }\end{array}$} & \multicolumn{6}{|c|}{ Cumulative mortality (\%) } \\
\hline & \multicolumn{2}{|c|}{8 DAI $^{1}$} & \multicolumn{2}{|c|}{10 DAI } & \multicolumn{2}{|c|}{12 DAI } \\
\hline & $0,0( \pm 0,00)$ & $\mathrm{a}^{2}$ & $0,0( \pm 0,00)$ & $\mathrm{b}$ & $0,0( \pm 0,00)$ & $\mathrm{b}$ \\
\hline $\mathrm{F} 1^{3}$ & $3,3( \pm 0,18)$ & $\mathrm{a}$ & $8,3( \pm 0,28)$ & $\mathrm{b}$ & $11,7( \pm 0,32)$ & $\mathrm{b}$ \\
\hline $\mathrm{F} 4^{3}$ & $6,7( \pm 0,25)$ & $\mathrm{a}$ & $61,7( \pm 0,49)$ & $\mathrm{a}$ & $93,3( \pm 0,25)$ & $\mathrm{a}$ \\
\hline $\mathrm{F} 7^{3}$ & $11,7( \pm 0,32)$ & $\mathrm{a}$ & $50,0( \pm 0,50)$ & $\mathrm{a}$ & $93,3( \pm 0,25)$ & $\mathrm{a}$ \\
\hline
\end{tabular}

Caption: ${ }^{1} \mathrm{DAI}$ - days after infection. ${ }^{2}$ Averages followed by different letters in the same column differ by StudentNewman-Keuls test at 5\% error probability. ${ }^{3} \mathrm{~F} 1$ - first passage of the virus; F4 - fourth passage of the virus; F7 seventh passage of the virus. $n=60$.

Source: the authors.

Table 2 - Number of viral polyhedrons $\left(\mathrm{OB} \cdot \mathrm{mL}^{-1}\right)$ after extraction in S. cosmioides caterpillars infected with different passages of AfMNPV.

\begin{tabular}{cccc}
\hline \multirow{2}{*}{ DAI $^{1}$} & \multicolumn{3}{c}{ Viral polyhedrons $\left(\mathbf{O B} \cdot \mathbf{m L}^{-1}\right)$} \\
\cline { 2 - 4 } & $\mathbf{F 1}^{\mathbf{2}}$ & $\mathbf{F 4}^{\mathbf{2}}$ & F7 $^{\mathbf{2}}$ \\
\hline 5 & $2,50 \times 10^{5}$ & $7,75 \times 10^{6}$ & $7,00 \times 10^{5}$ \\
10 & $4,85 \times 10^{6}$ & $3,14 \times 10^{7}$ & $1,64 \times 10^{7}$ \\
\hline
\end{tabular}

Caption: ${ }^{1} \mathrm{DAI}$ - days after infection. ${ }^{2} \mathrm{~F} 1$ - first passage of the virus; F4 - fourth passage of the virus; F7 - seventh passage of the virus. $\mathrm{n}=10$.

Source: the authors.

Figure 1 - Development of $S$. cosmioides caterpillars infected with different passages of $A f \mathrm{MNPV}$, 10 days after infection.

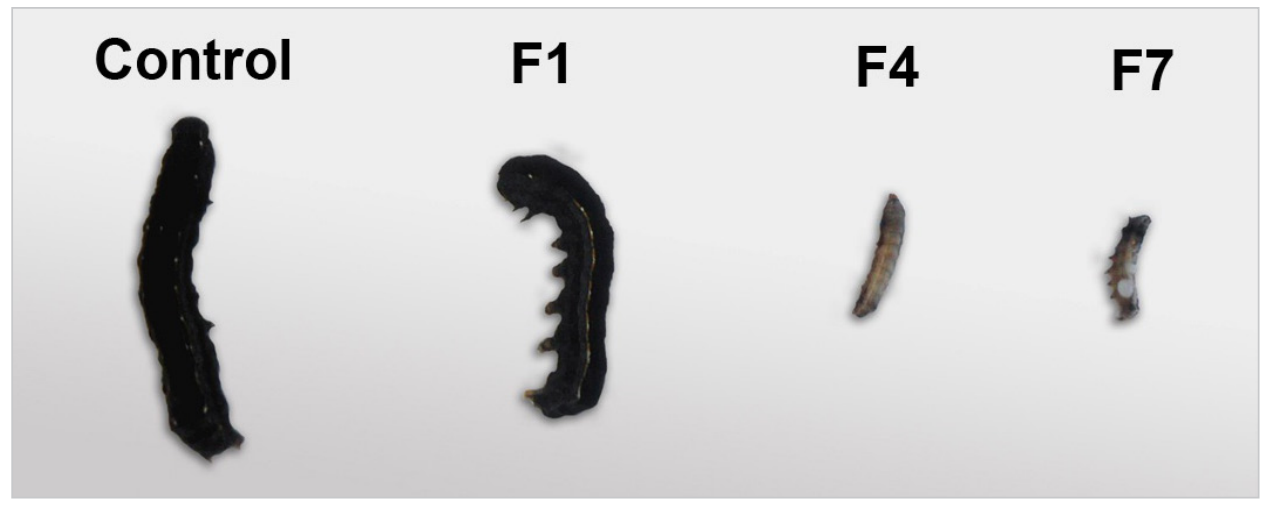

Caption: F1 - first passage, F4 - fourth passage and F7 - seventh passage of the virus.

Source: the authors.

Midgut morphology of S. cosmioides caterpillars non-infected with AfMNPV (control)

The midgut histologically is constituted from lumen to the periphery of the peritrophic membrane (PM), the epithelial layer (EL) and muscle layer (ML) (Figures 2A, 3A and 4A). The $\mathrm{PM}$ is an acellular layer just above the epithelium, which divides the lumen of the digestive tube in two environments, endo (Ed) and ectoperitrophic 
space $(\mathrm{Ec})$. Ed is in contact with food and separates it from the rest of the midgut, while Ec separates the epithelium from the PM. The EL is formed by a pseudostratified columnar epithelium with brush border, composed of three cells types: the columnar (Co), goblet (Gob) and regenerative cells ( $\mathrm{Re})$. Co, more abundant, are elongated, with some protrusions, brush border well-developed, nucleus in the midline to apical, basophil cytoplasm and little vacuolized. Gob is acidophilic, shaped like a cup and basal nucleus. Re are small, basophilic cells and central nucleus. They are found in small quantities, alone or grouped in nests, especially in the basal portion of the epithelium. The ML is composed of cross-fiber bundles (circular muscle), closer to the EL base, accompanying its folds, and longitudinalfiber bundles (longitudinal muscle) accompanying the EL throughout its length.

\section{F1 - first passage}

After 24 hours of infection (Figure 2B), comparing with the control (Figure 2A), we observed the PM fragmented and far from epithelium; more elongated $\mathrm{Co}$, apparently in greater quantity and greater number of protrusions and different stages of maturation; more vacuolated cytoplasm and unorganized brush border; apparent increase in the amount of $\mathrm{Re}$ and fragmentation of the longitudinal ML (Figure 2B). Within 72 hours, midgut presented fragmented MP; low epithelium; Co with unorganized brush border, few protrusions, very vacuolated cytoplasm, and nucleus in the median region. In addition, there was an increase in the number of Re, and fragmented ML (Figure 2C). After 144 hours, midgut resembled the control, with high epithelium, but apparently more Re (Figure 2D).

Figure 2 - Midgut photomicrograph of $S$. cosmioides larvae, control and infected with the first passage of AfMNPV: (A) control and (B) 24 hours, (C) 72 hours, (D) 144 hours, from infection.

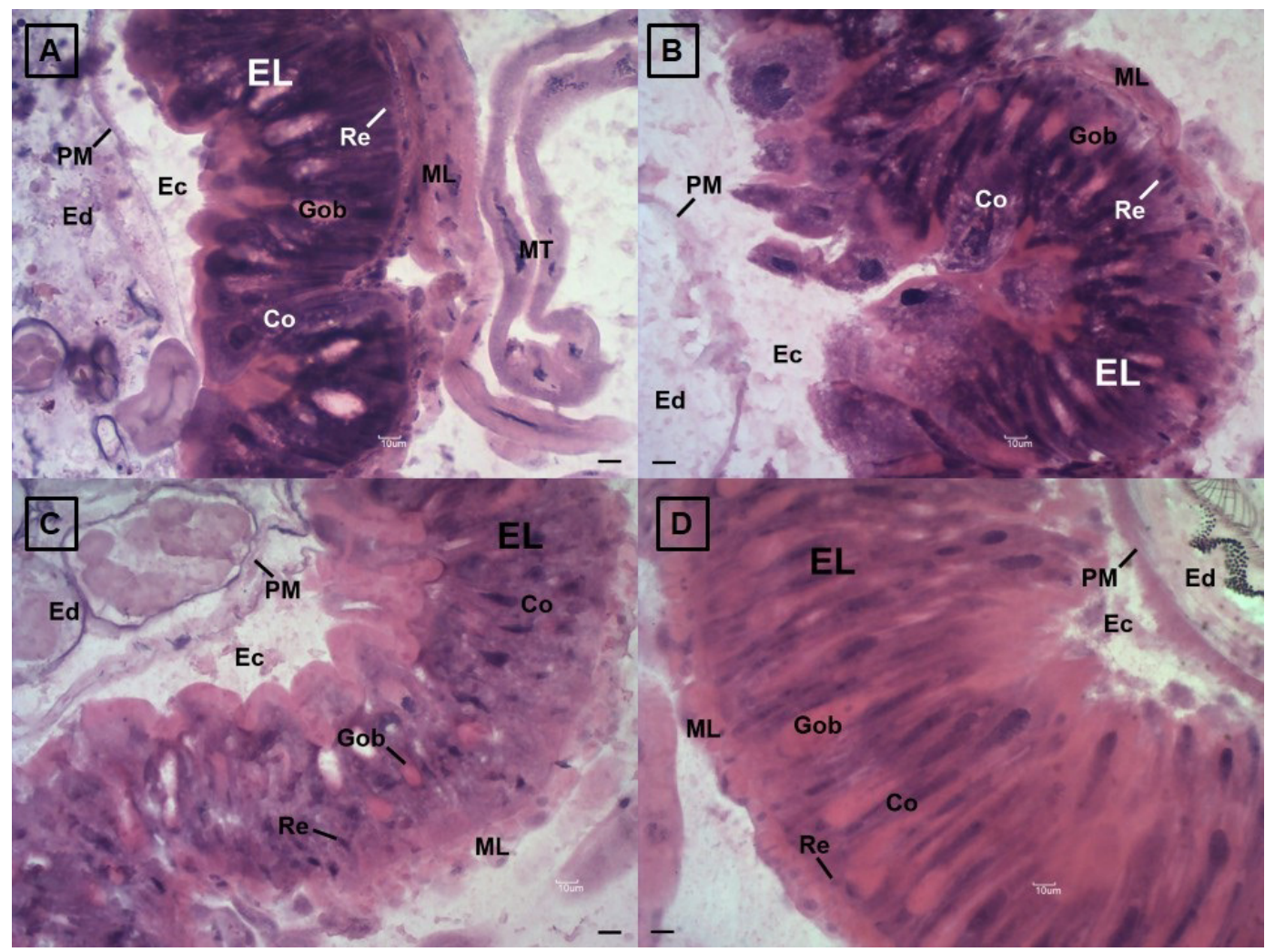

Caption: Peritrophic Membrane (PM); Endoperitrophic Space (Ed); Ectoperitrophic Space (Ec); Epithelial Layer (EL); Columnar Cell (Co); Goblet Cell (Gob); Regenerative Cell (Re); Muscle Layer (ML); Malpighian Tubule (MT). HE. Bar: $10 \mu \mathrm{m}$.

Source: the authors. 
F4 - fourth passage

Within 24 hours of infection, there was highly fragmented PM; epithelium apparently lower compared to control and other times of infection; Co quite changed, apparently in small numbers, with large vacuoles and practically no brush border. We can also note Re in larger amounts, in nests and hypertrophic. ML was thicker and more distant ofthe basal portion of the epithelial cells, moving towards the hemocoel, in relation to the control and had hypertrophic cells (Figure 3B). Within 72 hours, there was fragmented and distant PM epithelium; Co apparently in larger numbers compared to the previous time (24 hours of infection) with brush border, many protrusions, nucleus in the median to apical region, with cytoplasmic vacuoles. We have also observed visually, increased amount of Re, and fragmented ML (Figure 3C). Within 144 hours, PM was highly fragmented; the epithelium was with great cellular disorganization and was difficult to see the cells. Co had unorganized brush border, little vacuolated cytoplasm, and nucleus in the median to apical region. We also observed visually a large increase in the number of Re and fragmented ML. We have also noted some tracheas with probable infection (Figure 3D).

Figure 3 - Midgut photomicrograph of S. cosmioides larvae, control and infected with the fourth passage of AfMNPV: (A) control and (B) 24 hours, (C) 72 hours, (D) 144 hours, from infection.

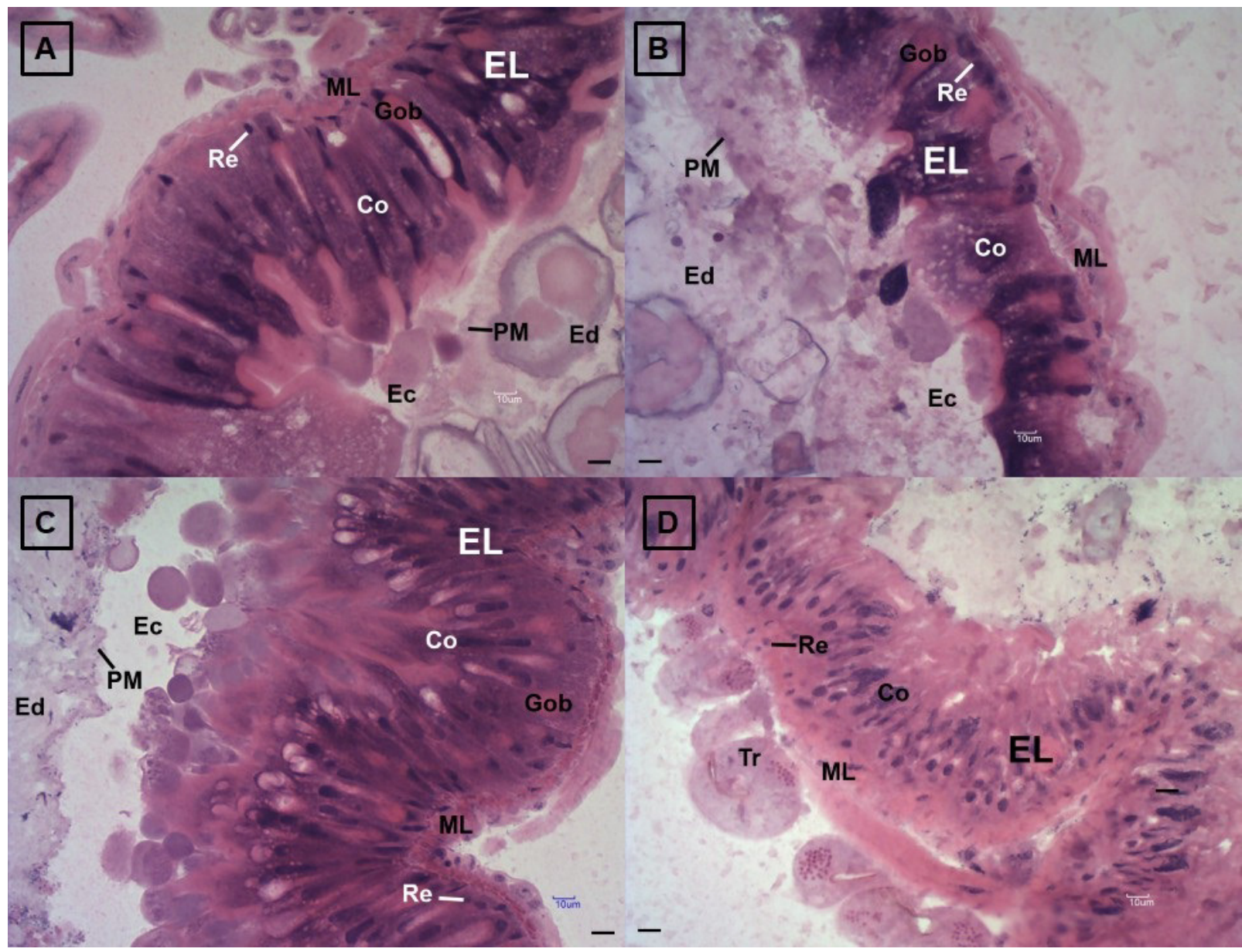

Caption: Peritrophic Membrane (PM); Endoperitrophic Space (Ed); Ectoperitrophic Space (Ec); Epithelial Layer (EL); Columnar Cell (Co); Goblet Cell (Gob); Regenerative Cell (Re); Muscle Layer (ML); Malpighian Tubule (MT). HE. Bar: $10 \mu \mathrm{m}$.

Source: the authors. 
F7 - seventh passage

Within 24 hours of infection, although PM was far from epithelium, it was little fragmented. The epithelium was low, and Co had very vacuolated cytoplasm, with brush border quite visible and thick, and nucleus in the median region. An apparent increase was noted in Re. The ML was fragmented (Figure 4B).

After 72 hours, the PM was fragmented and very distant from the epithelium. The epithelium was low; Co had little unorganized brush border, many protrusions, vacuolated cytoplasm, and visible increase in the amount of Re. The longitudinal ML was fragmented (Figure 4C). Within 144 hours, PM was little fragmented and quite far from the epithelium. The epithelium was still low, we could note Co at different stages of maturity, with little unorganized brush border, nucleus mostly in the apical region and cytoplasm with little vacuolation. We also observed an increase in the amount of Re. The ML was slightly fragmented (Figure 4D).

Figure 4 - Midgut photomicrograph of $S$. cosmioides larvae, control and infected with the seventh passage of AfMNPV: (A) control and (B) 24 hours, (C) 72 hours, (D) 144 hours, from infection.

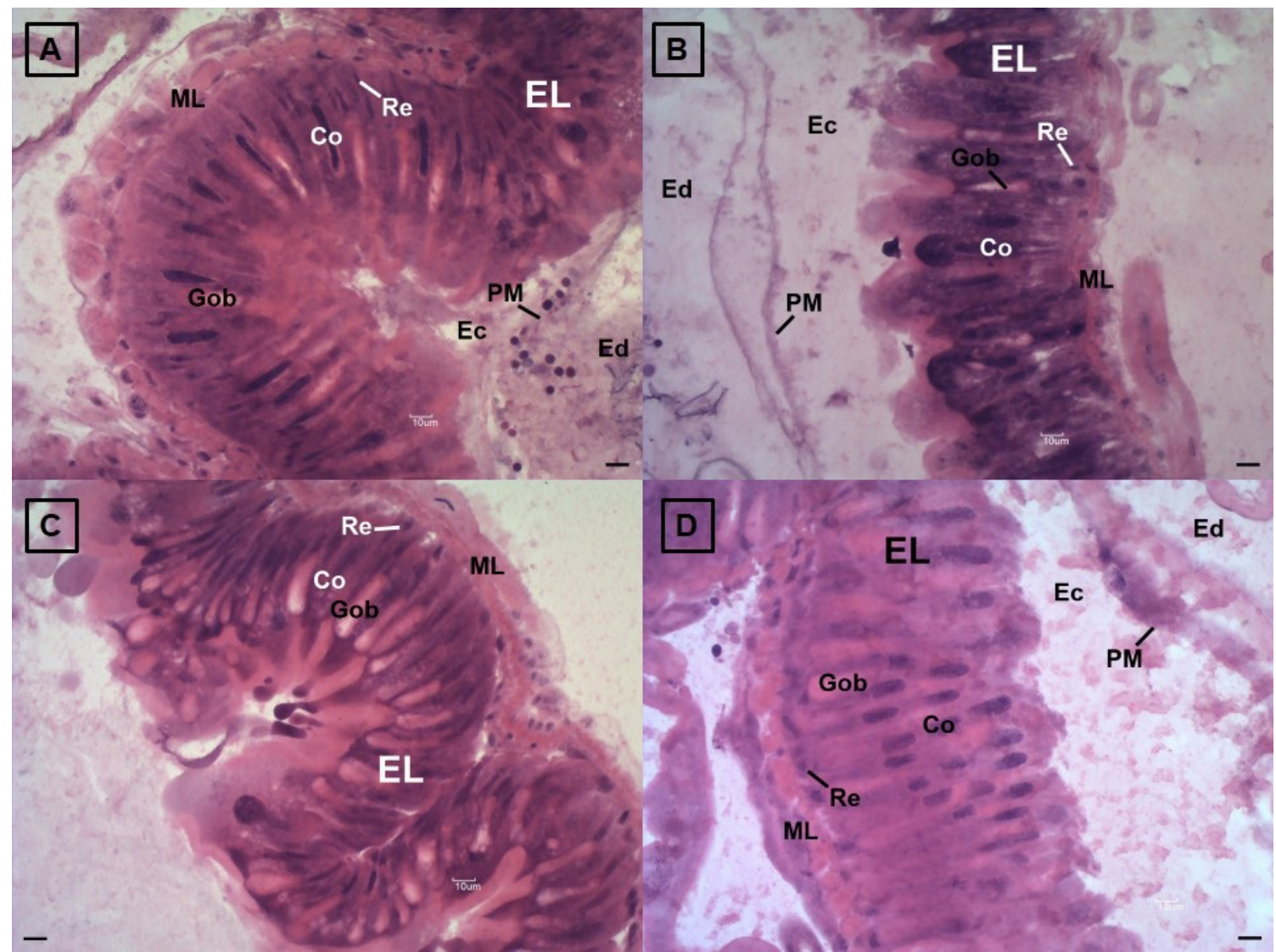

Caption: Peritrophic Membrane (PM); Endoperitrophic Space (Ed); Ectoperitrophic Space (Ec); Epithelial Layer (EL); Columnar Cell (Co); Goblet Cell (Gob); Regenerative Cell (Re); Muscle Layer (ML). HE. Bar: $10 \mu \mathrm{m}$.

Source: the authors.

\section{Discussion and Conclusion}

The results of mortality and behavioral aspects in relation to the control and F1 treatment development showed that the larval period, along with pre-pupa, was 32 to 33 days and from 25 to 26 days, respectively. The results for the control were close to those found by Bavaresco et al. ${ }^{(12)}$ in laboratory studies with $S$. cosmioides they noted that the development of larvae, along with the 
pre-pupa, totalizes 30.4 days. This small temporal variation can be explained by the fact that the authors worked with soybean leaves "in nature" as a feeding source, and this study used the Anticarsia gemmatalis diet adapted to $S$. cosmioides $^{(13)}$ which may have resulted in a difference in insect development speed.

Regarding the locomotion and feeding abilities of the caterpillars infected by F4 and F7 treatments, the results are corroborated by Moscardi et $a l .{ }^{(7)}$ These authors reported that, in general, caterpillars infected by viruses lose their motor and feeding abilities approximately four days after inoculation. These same authors reported that the caterpillars usually died from six to ten days after infection. In this study, 10 days after infection, a rate of $61.67 \%$ mortality was observed. This mortality may be associated probably to AfMNPV, that it is a non-specific virus, where there is little knowledge about its infection in $S$. cosmioides. The results highlight the need for more studies on the AfMNPV and $S$. cosmioides interaction.

Overall, our results allow the conclusion that although the mortality commence later in F4 and F7 treatments, there is a positive effect of the virus on the $S$. cosmioides control, and, although there was no significant mortality, as in the F1 case, the fact that the caterpillars and moths present a delay and/or deformation during development causes a reduction of the damage caused by caterpillars to crops attacked. Similar results were reported by Morales et al. ${ }^{(14)}$ working with sequential passages of AcMNPV into Chrysodeixis includes and Anticarsia gemmatalis, observed increased virulence and mortality for each passage of the virus in both species.

Morphologically, the gut of this pest was similar to that reported in other species of Lepidoptera, as described in A. gemmatalis, ${ }^{(15-17)}$ Diatraea saccharalis, ${ }^{(18)}$ Manduca sexta and Heliothis virescens $^{(19)}$ and Alabama argilacea ${ }^{(20)}$ being formed by the epithelial layer, covered by a membrane, called peritrophic membrane and surrounded by a muscular layer. The PM is an acellular structure that separates the epithelium from the intestinal contents, protecting it against abrasion and acting as a permeable barrier to digestive enzymes and digestion products. ${ }^{(21-22)}$ This membrane consists of a fine network composed of chitin, glycosaminoglycans, glycoproteins and proteins. ${ }^{(15-17,21-24)}$ Wang and Granados ${ }^{(23)}$ reported that this structure also serves as a barrier that prevents or hinders the entry of micro-organisms in the epithelium. It can be said that the functionality of this membrane or matrix is altered in this work, since we observed PM fragmentation in the treatments F4 and F7, being more evidenced in this last treatment. According Tellam, ${ }^{(24)}$ Chapman $^{(9)}$ and Terra ${ }^{(22)}$ PM stimulates the digestive processes and protects the surface of the epithelium from mechanical abrasion and the action of toxins and pathogens ingested along with food. The rupture of this structure could be associated with thein tense disorganization of the columnar cells and consequently your synthesis ${ }^{(15-17)}$ and once ruptured, the virus comes to have free access to further infection and complete its cycle in epithelial cells. In the midgut epithelial layer, as well as other lepidopteran described by Levy et al., ${ }^{(15)}$ Pinheiro et al. ${ }^{(18)}$ and Cruz et al.. ${ }^{(15)}$ we can see three cell types, the columnar, goblet and regenerative cells. The columnar cells are described as digestive cells and considered the most numerous in the epithelium, easily identified by light microscopy, with basophilic cytoplasm and acidophilic brush border. $^{(15,17,20,25-26)}$

According to Levy et al. ${ }^{(15)}$ cytoplasmic portions can be released into the ectoperitrophic space. These features were also observed in $S$. cosmioides in this work. The apical cytoplasmic protrusions released in the ectoperitrophic space were characteristic in all treatments, like that observed by Levy et al. ${ }^{(15)}$ and Cruz et al..$^{(17)}$ These protrusions can be considered as a mechanism of resistance to infection by virus, associated with cell death, since when the midgut is infected by microbial agents, columnar cells swell and form apical protuberances releasing all their content into the lumen, in addition to being responsible for the apocrine secretion of digestive enzymes into the lumen. ${ }^{(26-28,30)}$ 
The columnar cells showed basophil cytoplasm, and this qualitative aspect differed from those observed by Correia et al. ${ }^{(29)}$ in $S$. frugiperda, who described columnar cells with acidophilic cytoplasm in midgut for this species. When comparing midgut larvae infected with AfMNPV in different treatments with control midgut larvae, the results show that the greatest changes were observed in the epithelial layer of midgut, especially in the columnar cells. This result is similar to Keddie et $a l .{ }^{(31)}$ who studied the infection of AcMNPV in Trichoplusi ani, they reported that the initial infection of this virus occurs in the columnar and regenerative cells from midgut epithelial layer.

The regenerative cells of $S$. cosmioides are similar to the described by Levy et al. ${ }^{(15-16)}$ and Pinheiro et al. ${ }^{(18)}$ These authors report that in the epithelial layer of $A$. gemmatalis and D. saccharalis, respectively, these cells were found in isolation, or paired groups in the basal area of the epithelium, are round or oval with strongly basophilic cytoplasm, and could be related to the epithelial cell renovation process that consists of substituting older or damaged cells. ${ }^{(17)}$ Regenerative cells observed in larger amounts in the three treatments and all infection times, compared to the control. According to Billingsley and Lehane, ${ }^{(8)}$ Chapman $^{(9)}$ and Cavalcante and Cruz-Landim ${ }^{(32)}$ are mainly related to the process of epithelial renewal, where the cells removed are replaced by regenerative cells. Engelhard and Volkman ${ }^{(33)}$ and Hoover et al..$^{(34)}$ reported that the cell spare capacity conferred to the epithelium could reduce susceptibility to viruses. Loeb et al. ${ }^{(35)}$ explained that the renewal of intestinal epithelium promotes the disposal of cells that can be infected by the virus, hindering thereby virus replication and establishment of a secondary infection in the body. In this context, F1 treatment, at 144 hours post infection, as observed, appears to have tackled the virus, and whereas the regenerative cells may have played a crucial role in this process. Perhaps the high virulence observed in F4 and F7 treatments, it was not possible to observe the same retrogression of infection in these treatments.
Goblet cells are also similar to other lepidopteran described in the literature. ${ }^{(15-18,30)}$ It has a calyx shape, with a large basal region, acidophilic cytoplasm, and basal nucleus. Its main function performing the transport of potassium from the hemolymph into the lumen, maintaining homeostasis and cooperating with columnar cells on the absorption of metabolites. In this work, we did not observe relevant changes to goblet cells in all treatments, unlike Cruz et al. ${ }^{(17)}$ who observed changes in these cells, where they detected cell voluminous and with an apparent increase in the quantity. According to these authors, this can alter the alkalinization of the midgut, and consequently, deficiency in food digestion, and could be related to the tested genotypes.

According Moscardi et al. ${ }^{(7)}$ after primary infection, where occurs the release of viral nucleocapsids and entering the microvilli, these nucleocapsids migrate to the basement membrane or also through the trachea, in the form of extracellular virus, which are responsible by secondary infection. This infection can be observed by changing some tracheas of the F4 treatment with 144 hours of infection. Changes observed in muscle layer, such as thicker and more distant from basal portion of epithelial cells, moving towards the hemocoel, in relation to the control and apparently with hypertrophic cells, may affect the architecture and functionality of the digestive tube, resulting in lower intestinal motility and thus lower utilization of ingested food. These changes can adversely affect the process of digestion, metabolic changes with the hemolymph and other organs such as fat body, altering the functional integrity of the tested larvae midgut, and thus, these larvae development can be impaired or even not complete.

In this work, we can conclude that the Anagrapha falcifera multiple nucleopolyhedrovirus, AfMNPV, causes behavioral changes and high mortality in S. cosmioides larvae in fourth and seventh passages tested, while the first passage promotes deformation in adult $S$. cosmioides, and may impair the next generation. From the three tested AfMNPV virus passages, the fourth and seventh 
passages are the most effective for the control of $S$. cosmioides, since they cause great morphological changes in the midgut epithelium, responsible for the digestion and absorption of food. Thus, the use of $A f \mathrm{MNPV}$ virus as a biological control agent for this pest is presented as promising, but field studies and greater knowledge on the virus-insect relationship are necessary to validate this fact.

\section{Acknowledgments}

To Coordenação de Aperfeiçoamento de Pessoal de Nível Superior (CAPES) and Escritório de Apoio ao Pesquisador, Pró-reitoria de Pesquisa e Pós-graduação, of the Universidade Estadual de Londrina (EAPq/PROPPG/UEL), for their financial support.

\section{References}

1 Piovesan M, Specht A, Carneiro E, Paula-Moraes SV, Casagrande MM. Phenological patterns of Spodoptera Guenée, 1852 (Lepidoptera: Noctuidae) is more affected by ENSO than seasonal factors and host plant availability in a Brazilian Savanna. Int. J. of Biometeorol. 2018;62:41322.

2 Habib MEM, Paleari LM, Amaral MEC. Effect of three larval diets on the development of the armyworm, Spodoptera latifascia Walker, 1856 (Noctuidae: Lepidoptera). Rev. Bra. de Zool. 1983;1:77-182.

3 Hostetter DL, Puttler B. A new broad host spectrum nuclear polyhedrosisvirus isolated from a celery looper, Anagrapha falcifera (Kirby), (Lepidoptera: Noctuidae). Environ. Entomol. 1991;20:1480-88.

4 Moscardi F. Utilização de vírus para controle da lagarta da soja. In: Alves SB, editor. Controle microbiano de insetos. São Paulo: Manole; 1986. p. $188-202$.

5 Moscardi F. Assessment of the applications of baculoviruses for control of Lepidoptera. Annu. Rev. Entomol. 1999;44:257-89.
6 Szewczyk B, Rabalski L, Krol E, Sihler W, Souza ML. Baculovirus biopesticides: a safe alternative to chemical protection of plants. J. Biopest. 2009;2:209-16.

7 Moscardi F, Cunha F, Moscardi ML. Vírus entomopatogênicos como componentes de programas de manejo integrado de pragas. Cienc. Amb. 2011;43.

8 Billingsley PF, Lehane MJ. Structure and ultrastructure of the insect midgut. In: Lehane MJ, Billingsley PF, editors. Biology of the Insect Midgut. London: Chapman \& Hall; 1996. p. 3-30.

9 Chapman, RF. The insects: structure and function. 5a ed. Cambridge: Harvard University Press; 2013.

10 Mordue (Luntz) AJ, Blackwell A. Azadirachtin: An update. J. Insect Physiol. 1993;39:903-24.

11 Mordue (Luntz) AJ, Nisbet AJ. Azadirachtin form the neem tree Azadirachta indica: its action against insects. An. Soc. Entomol. Bra. 2000;29:615-32.

12 Bavaresco A, Garcia MS, Grutzmacher AD, Ringenberg R, Foresti J. Biologia comparada de Spodoptera cosmioides (Walk.) (Lepidoptera: Noctuidae) em cebola, mamona, soja e feijão. Cienc. Rural. 2003;33(6):993-8.

13 Bavaresco A, Garcia MS, Grützmacher AD, Ringenberg R, Foresti J. Adequação de uma dieta artificial para a criação de Spodoptera cosmioides (Walk.) (Lepidoptera: Noctuidae) em Laboratório. Neotrop. Entomol. 2004;33 (2):155-61.

14 Morales L, Moscardi F, Gravena S. Potencial do baculovírus de Autographa californica (Speyer) no controle de Chrysodeixis includens (Walker) e Anticarsia gemmatalis Hübner (Lep.: Noctuidae). Pesq. Agropec. Bras. 1993;28(2): 237-43.

15 Levy SM, Falleiros AMF, Gregório EA, Arrebola NR, Toledo LA. The larval midgut of Anticarsia gemmatalis (Hübner) (Lepidoptera: Noctuidae): light and electron microscopy studies of the epithelial cells. J. Biol. 2004;64 (3):1-6. 
16 Levy SM, Moscardi F, Falleiros AMF, Silva RJ, Gregório EA. A morphometric study of the midgut in resistant and non-resistant Anticarsia gemmatalis (Hübner) (Lepidoptera: Noctuidae) larvae to its nucleopolyhedrovirus (AgMNPV). J. Invertebr. Pathol. 2009;101:17-22.

17 Cruz NA, Hoffmann-Campo CB, Levy SM, Falleiros AMF. Post-ingestive effects of flavonoids in the midgut epithelium of Anticarsia gemmatalis (Hübner 1818) (Lepidoptera: Erebidae) larvae. Semina: Ciênc. Biol. Saúde. 2017;38(2):185-92.

18 Pinheiro DO, Quagio-Grassiotto I, Gregório EA. Morphological regional differences of epithelial cells along the midgut in Diatraea saccharalis Fabricius (Lepidoptera: Crambidae) larvae. Neotrop. Entomol. 2008;37(4):413-9.

19 Hakim RS, Baldwin KM, Loeb M. The role of stem cells in midgut growth and regeneration. In vitro cell. Dev. 2001;37(6):338-42.

20 Sousa MEC, Santos FAB, Wanderley-Teixeira V, Teixeira AAC, Siqueira HAA, Alves LC, et al. Histopathology and ultrastructure of midgut of Alabama argillacea (Hübner) (Lepidoptera: Noctuidae) fed Bt-cotton. J. Insect Physiol. 2010;56(12);1913-19.

21 Eisemann $\mathrm{CH}$, Binnington KC. The peritrophic membrane: Its formation, structure, chemical composition and permeability in relation to vaccination against ectoparasitic arthropods. Int. J. Parasitol. 1994;24(1):15-26.

22 Terra W. The origin and functions of the insect peritrophic membrane and peritrophic gel. Arch. Insect Biochem. Physiol. 2001;47: 4761.

23 Wang P, Granados RR. Molecular structure of the peritrophic membrane (PM): Identification of potential PM target sites for insect control. Arch. Insect Biochem. Physiol. 2001;47(2): 110-8.

24 Tellam RL. The peritrophic matrix. In: Lehane MJ, Billingsley PF. (Eds.) Biology of the Insect Midgut. London: Chapman \& Hall; 1996. p. $86-114$
25 Okuda K, Almeida F, Mortara RA, Krieger $\mathrm{H}$, Marinotti O, Bijovsky AT. Cell death and regeneration in the midgut of the mosquito, Culex quinquefasciatus. J. Insect Physiol. 2007; 53(12):1307-15.

26 Fialho MCQ, Zanuncio JC, Neves CA, Ramalho FS, Serrão JE. Ultrastructure of the digestive cells in the midgut of the predator Brontocoris tabidus (Heteroptera: Pentatomidae) after different feeding periods on prey and plants. Ann. Entomol. Soc. Am. 2009;102:119-27.

27 Washburn JO, Wong JF, Volkman LE. Comparative pathogenesis of Helicoverpa zea nucleopolyhedrovirus in noctuid larvae. J. Gen. Virol. 2001;82(7):1777-84.

28 Hakim RS, Baldwin K, Smagghe G. Regulation of midgut growth, development, and metamorphosis. Annu. Rev. Entomol. 2010;55:593608.

29 Correia AA, Wanderley-Teixeira V, Teixeira AAC, Oliveira JV. Morfologia do canal alimentar de lagartas de Spodoptera frugiperda (J E Smith) (Lepidoptera: Noctuidae) alimentadas com folhas tratadas com nim. Neotrop. Entomol. 2001;38(1):83-91.

30 Santos CD, Ribeiro AF, Ferreira C, Terra WR. The larval midgut of cassava hornworm (Erinnyis ello): ultrastructure, fluid flux and the secretory activity in relation to the organization of digestion. Cell Tissue Res. 1984;237:56574.

31 Keddie BA, Aponte GW, Volkman LE. The pathway of infection of Autographa californica nuclear polyhedrosisvirus in an insect host. Science. 1989;243(4899):1728-30.

32 Cavalcante VM, Cruz-Landim C. Types of cells present in the midgut of the insects: a review. Naturalia. 1999;24:19-39.

33 Engelhard EK, Volkman LE. Developmental resistance in fourth instar Trichoplusi ani orally inoculated with Autographa californica M nuclear polyhedrosisvirus. Virology. 1995;209(2): 384-9. 
34 Hoover K, Washburn JO, Volkman LE. Midgut-based resistance of Heliothis virescens to baculovirus infection mediated by phytochemicals in cotton. J. InsectPhysiol. 2000;46 (6):999-1007.

35 Loeb MJ, Martin PAW, Narang N, Hakim RS, Goto S, Takeda M. Control of life, death, and differentiation in cultured midgut cells of the lepidopteran, Heliothis virescens. In Vitro Cell.

Dev - An. 2001;37(6):348-52. 
